УДК 821.163.41-2.09 Марковић, Милена https://doi.org/10.18485/godisnjak.2020.15.17

Марија Мијаиловић*

Универзитет у Београду

Филолошки факултет, докторанд
Оригинални научни рад

Примљен: 15. 09. 2020.

Прихваћен: 10. 11. 2020.

\title{
ДИДАСКАЛИЈЕ КАО ТИП ГОВОРА У ДРАМСКОМ СТВАРАЛАШТВУ МИЛЕНЕ МАРКОВИЋ
}

У овом раду биће приказане и анализиране дидаскалије као тип драмског говора који се јавља у драмама Милене Марковић." Дидаскалије се издвајају као тип драмског говора који доприноси изградњи радње и идеја драма. Оне су, заправо, нужан алат за стварање целовитог драмског дела. Функције које овај тип говора има у драмама Милене Марковић наметнуле су одређену композицију поглавља, прецизније, свако поглавље испитује како одређено својство дидаскалија утиче најпре на радњу драме, а затим и на њене друге аспекте. Анализом овог типа драмског говора биће обухваћене следеће драме ове ауторке: Павиљони, Шине, Брод за лутке, Наход Симеон, Шума блиста, Жица и Змајеубице.

Кључне речи: савремена српска драма, дидаскалије, декор, упутства за глумце, Милена Марковић, епски театар

\section{Увод}

У дидаскалијама Милене Марковић јасно је уочљив уплив романескног, епског. Управо та њихова карактеристика их приближава ономе што се у теорији књижевности назива дидаскалијски роман ${ }^{1}$ (синтагма којом је

*marija.mijailovic5@gmail.com

** Овај рад представља део обимнијег истраживања које је за предмет анализе имало сва три типа драмских говора који се јављају у драмама Милене Марковић - дидаскалије, сонг, дијалог/монолог.

${ }^{1}$ Више о томе: Sarazak, Žan-Pjer. Leksika moderne i savremene drame. Vršac: KOV, 2009. 
одређена савремена драма са свим својим специфичностима). Дескриптивно својство дугих дидаскалија у драмама Милене Марковић има изузетну важност у целокупном систему који гради драму. Дидаскалије су вишеструко значајне, јер пружају информације које делују на више различитих аспеката драме. Учествују у градњи ликова, постављању почетне ситуације, опису декора, али и дају упутства за глумце и говоре о догађајима или стварима које нису обухваћене радњом драме а имају велики значај у њеној анализи и разумевању. Наиме, дидаскалије у драмама Милене Марковић одређују четири доминантна својства или садржаја: 1) утицај на радњу драме; 2) декор; 3) упутство за глумце; 4) сведочанство о времену које није обухваћено радњом драме. Свако од ова четири својства има двоструки утицај, прецизније, свако својство утиче на два поља - на саму радњу драме и на карактеризацију ликова. Имајући ово у виду, рад садржи четири поглавља која говоре о основним фукнцијама и садржајима које дидаскалије доносе.

Саме драме садрже мноштво примера, али се за потребе анализе и тумачења наводе само они који су репрезентативни и специфични.

\section{Утицај дидаскалија на радњу драме}

Драмама Милене Марковић неопходан је утицај дидаскалија на саму радњу. Наиме, радње ових драма не третирају изолован догађај од почетка до краја, већ се баве одређеним догађајем као последицом читавог дотадашњег живота јунака који не може бити покривен радњом драме због своје обимности. Ауторка жели да покаже и прикаже све оно што је у животу јунака довело до одређеног исхода. Сви ти ранији догађаји својим обимом опиру се драмској форми, па је уплив романескних дидаскалија неопходан како бисмо могли да пратимо радњу драме. Дефинишући савремену драму, којој припада и стваралаштво ове ауторке, Саразак је закључио: „Знамо да сваки Ибзенов комад са савременом темом настаје као епилог једног 'ненаписаног романа' и стога се не треба чудити што на површину драме испливавају, преко дидаскалија, читави делови тог виртуелног романа" (Саразак 2009: 26). ${ }^{2}$

Анализом дидаскалија у стваралаштву ове ауторке дошли смо до закључка да оне утичу на радњу драме на три начина из чега произилази њихова класификација на: а) дидаскалије уводног карактера; б) дидаскалије средишњег карактера; в) дидаскалије финалног карактера. У драмама Милене Марковић сама радња јавља се као наставак оних догађаја који су дати дидаскалијама уводног карактера. Обимност догађаја условила је и

\footnotetext{
${ }^{2}$ Више о томе: Sarazak, Žan-Pjer. Leksika moderne i savremene drame. Vršac: KOV, 2009.
} 
појаву друга два типа дидаскалија - дидаскалије средишњег и финалног карактера. Фрагментарност радње и дијалога употпуњена је управо овим типом дидаскалија. Не могу сви догађаји бити драматизовани, зато су они који то нису дати дидаскалијама.

\section{Дидаскалије уводног карактера}

Дидаскалије уводног карактера углавном су сажете и кратке, али ефектне. Без њих се не може пратити даљи ток радње, јер оне говоре о сцени која следи и постављају темеље за њу. Дидаскалије уводног карактера имају улогу да: а) мотивишу дијалог; б) дају информације о спољашњем и унутрашњем амбијенту под чијим утицајима јунак дела и под чијим се утицајима формирао; в) учествују у карактеризацији и изградњи ликова од чега зависи даље разумевање драме; г) дају информације о томе који јунак се трансформише у ког што је битно својство и идеја епског театра.

Дидаскалија ће нас увести у сцену у којој се појављује Мала у драми Павиљони (Марковић 2014: 019). Јасно је из дидаскалије да је Мацан изненађен оним што је видео испред врата. Његов нагли повратак у собу сведочи да ће и за брата то бити изненађујуће. Дошао је неко кога нису очекивали. На сцену ступа трећи лик чија је појава била неочекивана. Сада је ситуација постављена тако да репликама ликова ауторка одмах може и мора објаснити ко је Мала и зашто је њен долазак био неочекиван. Дакле, дијалог који ликови даље воде мотивисан је дидаскалијом.

Дидаскалија „Снифне кокаин.” (Марковић 2014: 044) и поред своје једноставности говори доста. Најпре је јасно да су актери зависници од кокаина, али нам ова дидаскалија говори и то шта се дешава када су под његовим дејством. Све што следи биће речено под дејством кокаина, чиме ауторка поставља проблем самоисповедања. Наиме, оно што ликови говоре под дејством кокаина углавном је нешто што их опседа и мучи. Углавном им је потребна нека врста подршке за ту врсту самоисповедања коју они налазе, нажалост, у дрогама.

У прву сцену драме Шине уводи нас слична дидаскалија (Марковић 2014: 067). Овом дидаскалијом група младих људи који ће бити актери наредне сцене јасно је окарактерисана. Однос између Јунака и Рупице је присан и за њих је потпуно природно да своју интиму деле са Гадним и Дебилом. Гадном је, такође, природно да присуствује ситуацији у којој се одвија нешто лично и интимно између двоје других људи и он ноншалантно пуши. За све њих ово је природно стање и редовна појава. Дебил који жели да им се придружи сведочи неприхватање од стране троје младих. Почетна 
ситуација је постављена, троје младих људи који су изгубили свест о личном и интимном проводе време заједно одбијајући да прихвате вршњака са одређеним менталним сметњама. Дакле, све што ће се даље десити десиће се у амбијенту потпуног одсуства слободе, личног, интимног и недвосмислене неспремности да се прихвати други и другачији.

На сличан начин ће ауторка поставити амбијент у ком се радња дешава у драми Шине (Марковић 2014: 080). Кључна реченица ове дидаскалије је „Гледају шта има, а нема ништа”. Дакле, два момка су у стању тренутног одсуства обавеза. Услед недостатка обавеза они гледају шта има, а знају да нема ништа, међутим, они и даље гледају. Њихово бесциљно гледање прекинуће појава пара тј. њихова појава ће их заинтересовати и они ће почети да их коментаришу. Дакле, то је амбијент у ком ће се десити све оно што следи. Имајући ово у виду, поставља се питање да ли је насиље које ће уследити већим делом проузроковано доконошћу и бесом. ${ }^{3}$

У драми 3мајеубице дидаскалије које се налазе на почетку сцена или појава ${ }^{5}$ углавном дају информације о томе који лик се трансформише у ког (Марковић 2014: 346).

Ово су, наравно, само неки од примера дидаскалија којима се ближе одређује атмосфера радње која следи, или којима се, пак, дају информације које су ван тока радње а за њу су битне.

\section{Дидаскалије финалног карактера}

За разлику од дидаскалија које нас на неки начин информишу и уводе у радњу која следи, за драме Милене Марковић карактеристичне су и оне које

\footnotetext{
${ }^{3}$ Насиље је у драмама Милене Марковић вишеструко мотивисано. С обзиром на то да се овај рад бави дидаскалијама као типом драмског говора, детаљна анализа насиља, положаја жене и осталих питања које ауторка покреће изостаће. Међутим, њих се бар оквирно морамо дотаћи управо ради анализе овог типа драмског говора који ауторка употребљава.

${ }^{4}$ Ова драма је сложенија од свих претходних драма Милене Марковић. Дидаскалије сведоче њену специфичност и ово је уједно једина драма у коју ауторка уводи светлећа слова као обавештење о локацији на којој се радња одвија. Специфичност и сложеност ове драме огледа се посебно у чињеници да у њој ауторка први пут истовремено користи и хор и сонгове. Њихова детаљна анализа дата је у поглављу које говори о сонговима у оквиру обимнијег истраживања чији је део и овај рад.

${ }^{5}$ Термине сцена или појава користимо само како бисмо прецизирали на шта мислимо. Они као такви нису употребљени у драмама Милене Марковић. Наиме, њене драме нису подељене на чинове, сцене или појаве. Њихова композиција је сложена и има јасно значење. Драме Павиљони, Шума блиста и Жииа подељене су на делове који су означени насловом, Шине и Брод за лутке су подељене на сцене, Наход Симеон је подељен на слике у оквиру насловљених поглавља, док је драма Змајеубице подељена на слике од којих је свака насловљена. Наслов сваког поглавља или слике није случајан и има вишеструку симболику.
} 
се налазе на крају неке сцене или појаве. Оне, углавном, завршавају сцену која им претходи тј. казују о њеном финалном исходу.

Снага и тежина завршних дидаскалија највише је испољена у оној којом се завршава драма Наход Симеон. Наиме, ликови на крају драме откривају у каквом су сродству и постају свесни својих грехова. Исход читаве драме дат је у дидаскалији која има завршни карактер - „Сви иду у воду.” (Марковић 2014: 233). Поред тога што даје информацију о догађају којим је финализована читава драма а не само једна сцена, ова дидаскалија појачава степен трагичности главих јунака откривајући њихово сродство. Степен трагичности којим је прожета драма само је најава за готово демонизовани крајњи исход који је дат дидаскалијом финалног карактера. На тај начин овај тип дидаскалије утиче на радњу драме и на њен идејни слој.

Такође, исход самоисповедања Мале, Ћопе Џиге и Мацана у драми Павиљони дат је у дидаскалији - , Она пуца себи у уста.” ${ }^{\prime 6}$ Мрак. Чује се како Џига вришти.” (Марковић 2014: 056). Цитирана дидаскалија финализује сцену која јој претходи, саопштава нам о њеном фаталном исходу, али говори нешто и о реакцији других јунака на такав крај. Џигин врисак свакако симболизује тешко прихватање и ужаснутост оним што се догодило.

Да дидаскалије којима се завршавају поједине сцене, епизоде или поглавља означавају и приказују финални исход онога што им претходи најбоље сведоче Звуци у драми Шине. Они се налазе у свим финалним дидаскалијама, а објашњени су у уводној дидаскалији ове драме - , ЗВУЦИ њима се завршава свака сцена. Они су комбинација клања свиња, хармонике, смеха, људских јаука $u$ запомагања, али тако помешани да се не распозна одмах шта је $y$ питању.” (Марковић 2014: 064).

\section{Дидаскалије средишњег карактера}

Поред ова два типа дидаскалија (оне којима одређено поглавље почиње и оне којима се нека целина завршава) постоје и оне које се јављају унутар самих сцена или појава. Означавамо их термином средишње јер су смештене у средишњи део појаве или сцене и из те позиције утичу на сам ток радње. Уочљиво је да се у њима, углавном, дају информације о насиљу које је над неким спроведено. Углавном је насиље у драмама Милена Марковић стационирано управо у дидаскалијама. То показују бројни примери у читавом драмском опусу ове ауторке (нпр. у драми Павиљони (Марковић 2014: 018), Шине (Марковић 2014: 070) и Наход Симеон (Марковић 2014: 204)).

\footnotetext{
${ }^{6}$ Ознака за нове пасусе у оквиру дидаскалија која ауторка прави у самом тексту.
} 
У драми Змајеубице насиље које се спроводи над младим револуционарима дато је у дидаскалијама - „Пале се светла. / Судница. Председник суда стоји и суди $у$ кругу светла. На свим странама на столицама седе оптужени. Кад причају они се осветле. Кад не причају њих туку, поје водом, бришу им крв, поливају их водом из кофа. Батине се одвијају у мраку. / Како сцена иде даље, тако Гаврила све више и више туку. Чубриловића само шамарају. Недељка туку. / Грабежа туку. Данила Илића брзо престану да туку." (Марковић 2014: 396).

\section{Декор}

Декор или опис сцене саставни је део дидаскалија у драмама Милене Марковић. Разликујемо два типа декора, тачније, две различите функције које декор у стваралаштву ове ауторке има. Најпре, декор има функцију да одреди јунака тиме што ће простор у ком се он креће симболично представљати не оно што јесте сам јунак, већ оно што јунак жели да буде, али чему не припада. Друга функција декора је да дочара специфично стање и атмосферу у којој се радња дешава.

Декор као представа онога што јунак није, али би желео да буде

Бокс који представља стан баба Добриле у драми Павиљони треба да изгледа овако: „Бокс са леве стране представља дневну собу у којој се налази сто са фиокама и две столице са јастучићима. ... / нацртани су миљеи, слике мртве природе, саксије по комодама и кавез са папагајем. ". (Marković 2014: 009). Бокс који треба да представља кухињу у стану Кнеза и његове породице описан је овако: „Бокс са десне стране представља велику кухињу, $u$ ту је велики трпезаријски сто са четири столице. ... / У другом стану живе Кнез, Лепа и Ћера, и преко целог зида је орман са разноразним тањирима, чашама $u$ флашама, љуте паприке, лук, слика Краља. ” (Marković 2014: 009). Последњи бокс који представља стан Џиге и Мацана, такође, је интересантно описан: „Бокс горе је већи простор, тавански, и ту су само две фотеље и музички уређај са два велика звучника. Све остало је нацртано $y$ стилу цртаних филмова Чака Џонса и Текса Ајворија. ... / Горе живе Мацан и Џига, немају ништа сем две фотеље и музичког уређаја, само нацртану каду и умиваоник и велику амблем - заставу Црвене Звезде на којој пише Делије.” (Марковић 2014: 009).

Јасно је да ауторка даје прецизан опис сцене. Она није сиромашна како то знају да буду сцене савремених драма, напротив. Очигледно је да је декор у тесној вези са ликовима који се у њему налазе. Ово нас враћа Золином тексту 
Натурализам у позоришту и периоду који означава прелаз са реализма на натурализам и по ком је простор у ком се јунак креће одраз њега самог. Јунак је онакав какав је простор. Поставља се питање да ли се Милена Марковић враћа натуралистичкој функцији декора. Несумњива је њена потреба да се декором каже нешто о самом јунаку, да се он управо декором у извесној мери окарактерише и дефинише. То свакако представља везу са натурализмом. Међутим, у драмама ове ауторке декор није једнако јунак, бар не у оном смислу у ком је то у натуралистичкој драми.

Дневна соба бабе Добриле је окрњена, баш као што је то и кухиња код Кнеза или стан код Мацана и Џиге. Добрилина дневна соба је таква да наслућујемо старицу која је своје слободно време посветила миљеима, цвећу и папагају. За простор у ком се одиграва радња везана за Кнеза и његову породицу није случајно изабрана кухиња. Кухиња треба да представља место на ком се породица окупља како би обедовала. Трпеза око које се окупља породица у патријархалном систему има јасно значење. Међутим, оно што се дешава у овој кухињи све је осим присног и нежног породичног окупљања. То је као простор резервисан за малтретирање и вређање Лепе. У њему се не обедује, у њему Кнез халапљиво гута све што се пред њега стави уз вечито негодовање и негативне коментаре на рачун припремљеног. Лепа и Ћера, углавном, не једу, већ само посматрају Кнеза за столом. Оне нису ту ради топлог породичног сусрета, већ да би саслушале дневну дозу придика и увреда. Стан Мацана и Џиги представља сенку и остатак породичног дома. Они имају само фотеље, постере и нацртану каду и умиваоник.

Сва три простора могла би да представљају натуралистички опис сцене само да нису порушена и осиромашена као што јесу. Наиме, ово су само остаци натуралистичког декора. То су остаци једне дневне собе, једне кухиње и једног стана. То је оно што слути на дневну собу или кухињу, али то није. Нешто у њиховом опису недостаје да би то била једна права и комплетна кухиња, дневна соба и стан. Тако порушен и осиромашен простор представља осиромашеног и порушеног јунака који се у њему креће. Простор више није као у натурализму оно што је јунак, већ оно што јунак треба да буде, оно за чим се ишло али што је неминовно измакло или оно одакле јунак потиче. Овај порушен простор каже - јунак би овако нешто желео, јунак би желео породицу окупљену око ручка, али они то нису. Простор је сањани идеал, нешто што је давно изгубљено, нешто чему јунак више не припада. Јунак не припада топлој породичној средини коју декор слути.

Јунаци се и сада смештају у одређен простор да би се о њима нешто рекло. Међутим, сада се не каже овај простор то је јунак, већ овај простор који слути топлу породичну атмосферу недостижни је идеал јунаку који се 
y њему креће. Декор представља огољени топли дом, али без обзира на своју осиромашеност то је и даље топли дом. Међутим, јунак својим особеностима не припада том систему сигурне и срећне породице коју декор наговештава.

Овако схваћен и третиран декор срећемо и у драми Наход Симеон: „Трбуљин стан је препун фигурица $u$ биста политичара, лепог мушкарца са дугом косом. Око фигурица су попаљене свеће. / Муж јој је непокретан, брбоће стално ко да свира трубу, разне химне. / Њих троје седе за вечером" (Марковић 2014: 209). Из дидаскалије видимо да је политика битан аспект за јунака који у овом простору обитава. Међутим, у репликама које следе потврдиће се специфичност декора у драмама Милене Марковић. Трбуља hе се јасно изјаснити као неко коме је некада био сан борба за боље уређен систем у ком ће просечан човек заузимати бољу позицију. Међутим, од тог се сна одустало, он сада постоји само у сећањима (види: Марковић 2014: 211). Бисте политичара су симбол идеала које је Трбуља имала, међутим, ти идеали су напуштени, о њима се сада само говори. Трбуља, дакле, није једнако оно што представља декор (политика, борба). Она том декору више не припада. Декор је оно чему се тежило, али што је неповратно отишло. У натурализму јунак јесте оно што представља простор, у драмама Милене Марковић јунак није оно што представља простор. Међутим, јасна је веза са натуралистичком поетиком - искористити простор у ком се јунак креће за изградњу његовог лика. У натурализму декор шаље поруку - ово је јунак, док ће у драмама Милене Марковић декор слати поруку - ово јунак није, ово је јунак желео да буде, ово је јунак некада био, ово је идеал који је јунаку недостижан. Карактеризација јунака на тај начин везана је за декор тј. декор гради лик истицањем онога што му је супротно и недостижно.

\section{Декор као представа специфичног стања и атмосфере $\boldsymbol{y}$ којој се радња дешава}

У драмама Милене Марковић има и таквих декора који су симбол специфичног стања и атмосфере у којима се јунак налази. Такав један декор налазимо у уводној дидаскалији драме Жица ${ }^{7}$ „„Радња се дешава на три дела

\footnotetext{
${ }^{7}$ Иако радња драме није прецизно лоцирана, она подсећа на специфичан живот српског становништва на Косову и Метохији. Више детаља у драми упућују на то: кућа ограђена жицом, кућа и њени становници су под сталним нишаном, константно присутни страни војници задужени да осигурају мир, страна новинарка која извештава, хуманитарна помоћ... Премијера драме изведена је управо на територији Косова и Метохије. Милена Марковић је и у својој поезији више пута опевала грађевине, места или јунаке који симболишу Косово и Метохију. Њена најпознатија песма ове оријентације и тематике је Малена Бағска. У интервју који је дала за Недељник 2016. године ауторка је истакла следеће: „Онда Жииа и Малена Бағска.
} 
сцене, међу крстовима. Када почне радња, крстови падају доле и стоје тако. Иду преко крстова сви. Могу да служе крстови и за столове и за сунчање и за љубав. И за клацкалицу. У близини мезар и нишани. / Горе је планина, ту има увек неко ко седи на џаковима и држи пушке и пије воду и ракију и једе бели хлеб. / Доле је Главна кућа и ограђено је бодљикавом жицом. Ко хоће да уђе у кућу, мора испод жице да се провуче. Празно је, а испод жице се уноси и храна и пиће.” (Марковић 2014: 277). Јасно је да је јунацима који обитавају у овом простору кретање ограничено. Кућа ограђена жицом симболизује удар на њихову слободу и породицу. Такође, они су стално на нишану, непрестано им прети опасност. Симболичан пад крстова и ход по њима сведочи и проблематизује однос према породици и традицији. Тај оскрнављен однос утиче на карактеризацију ликова и мотивацију њихових поступака и радње.

Слична је и друга дидаскалија ове драме која се налази у делу под називом Купање са певањем: „Главна кућа под жицом. / Кухиња. / Склоњено је све, корито на средини. Свуда џакови кромпира и брашна, кутије хуманитарне помоћи, картони сокова и млека." (Марковић 2014: 295). Дакле, јунаци се налазе у изузетно тешкој позицији. Њихово тренутно стање симболизује потреба за хуманитарном помоћу. Ово је уједно и тип уводне дидаскалије која даје информацију о томе у каквој се атмосфери збива оно што следи.

За пример овог типа декора, дакле, оног који означава специфично стање и атмосферу у којој се јунак налази, можемо узети и дидаскалију драме Брод за лутке: „Жена вришти. / Дрвеће завија, као да неко вришти, као да дете плаче, као да се смеје нека жена, не зна се како, али леди крв." (Марковић 2014: 166). Овај декор одговара постмодернистичком поимању простора према ком простор не обликује јунака, већ јунак обликује простор. ${ }^{8}$ Прецизније, природа неће бити шум ветра и цвркут птица, већ оно што јој јунак припише. У овом случају природа завија и вришти тако да то леди крв. Овај декор најављује готово демонизовану завршну фазу живота једне жене.

\section{Упутства за глумце}

Поред тога што утичу на развој драме и дају опис сцене на којој се иста одиграва, дидаскалије обилују упутствима за глумце. На основу њих видимо

Опет већ неколико година морам да одговарам на питања о Косову. Написала сам неке песме о мом осећању и верујем да оне изазивају љубав и патњу, вероватно ће те песме да остану и треба да се одвоје од моје личности, као све праве песме.” (Марковић 2016б).

${ }^{8}$ Више о томе: Пијановић, Петар. Модерна традиција: огледи из српске књижевности. Београд: Службени гласник, 2012. 
да Милена Марковић за начин глуме бира онај који је карактеристичан за Брехтово стваралаштво и епско позориште. Дакле, глумци својом игром треба да објашњавају, а не да представљају личност. ${ }^{9}$ Ауторка овај ефекат постиже најпре поделом улога која је назначена у дидаскалијама.

У уводној дидаскалији драме Шине Милена Марковић каже: „Једна глумица мора да игра све женске ликове и увек се зове Рупица. / Она је прво девојчица, затим школски психолог, затим лака женска, затим заробљеница у рату, затим медицинска сестра. У рају је заробљеница. / Глумац који игра јунака не може да игра друге улоге. / Сви остали ликови могу да се комбинују. / Пацароши и Домороци такође могу да се комбинују.” (Марковић 2014: 064-065). Чињеница да један глумац игра више различитих улога тј. да игра више различитих ликова, спречава онога који гледа или чита да се аристотеловски уживи у тај лик. Ова појава нас тера, баш онако како је Брехт замислио, да не пратимо слепо судбину одређеног лика, већ да посматрамо и сазнајемо свет. Овим се не тежи потреби да публика осети бол, терет или срећу лика који посматра, већ потреби да критички сагледа тог лика, да га у потпуности спозна. До спознаје не долази путем изједначавања, већ путем посматрања. Чињеница да један глумац игра више ликова ослобађа нас евентуалне идентификације и помаже у јасном посматрању тог лика и света.

Чињеница да у драми Шине једна глумица игра све женске ликове утиче и на њен идејни слој. Дакле, овим се жели рећи да је третман друштва према жени исти без обзира на узраст, образовање и позицију коју она у истом заузима. ${ }^{10}$

\footnotetext{
${ }^{9}$ Више о томе: Breht, Bertolt. Mali organon za teatar. Dijalektika u teatru. Beograd: Nolit, 1966.

${ }^{10}$ Проблем положаја и третмана који жена има у друштву једно је од основних питања којим се у свом драмском стваралаштву бави Милена Марковић. Не постоји ниједна њена драма која не третира ово питање. Ауторка приказује страшан положај жене у савременом друштву. Према њеној представи жена је жртва сваког облика насиља. На скали од сексуалног и физичког до духовног и менталног не постоји врста насиља која је заобилази. Жена је малтретирана без обзира на узраст, образовање или било који други аспект. Једна глумица, каже ауторка у драми Шине, мора да игра све женске ликове. Дакле, једна глумица играће и тинејџерку и зрелу жену. Све женске улоге глумица ће одиграти под једним и симболичним именом Рупица које, можда, најбоље сведочи како је друштво види и третира. За разлику од ове драме која говори о више жена различитог узраста које све без изузетка трпе насиље, драма Брод за лутке говори о животу само једне жене. Међутим, та једна жена је у сваком периоду свог живота била жртва насиља. Посебно је питање какве је последице вишегодишње насиље оставило на ту жену. Након претрпљеног насиља и сваког облика дискриминације, њена појава је у последњој сцени која носи наслов Ивица и Марица готово демонизована. Ауторка у уводној дидаскалији драме Шине експлицитно износи намеру да пише о положају жене: „Не треба да буде тога јер је ово метафора о насиљу, пре свега према Жени.” (Марковић 2014: 065).
} 
Брехтовски начин глуме потврђује и информација о глумцима и њиховом понашању на сцени дата у уводној дидаскалији драме 3мајеубице: „У промени сценографије и хорском певању учествују сви који не играју и који се не пресвлаче.” (Марковић 2014: 339). Замисао да сви глумци буду на сцени и да учествују у промени декора или костима иде у прилог теорији по којој глумац треба да објашњава, а не представља личности. Константним присуством на сцени и учешћем у техничкој припреми за наредну појаву, глумци као да опомињу гледаоце да они нису личности које глуме, они те личности само објашњавају. Овакво њихово понашање на сцени готово да онемогућава идентификацију и захтева искључиво посматрање. Ова драма обилује дидаскалијама које су уводног типа и у којима се дају слична упутства - „Светлећа слова пише ВЕЛИКИ СВЕТ. / Весела музика. Они се претварају, Сањана девојка у Курву, Асистент у Кафеџију, Жандар други у Педера, Европски научник у Гаћиновића. Бела госпођа се претвара у Вајара. Зрели мушкарац скида бели мантил и претвара се у Троцког. Седне поред Гаћиновића. Вајар прави главу од новина.” (Марковић 2014: 353).

Посебно ефектно и корисно за формирање брехтовског начина глуме је упутство по ком глумци треба да преузму и улогу животиња (Марковић 2014: 349).

Сведочанство о времену које није обухваћено радњом драме

Дидаскалије у драмама Милене Марковић обилују информацијама о прошлости актера драме тј. о збивањима која нису обухваћена њеном радњом. Прецизније, разликујемо два типа ових дидаскалија. Прва функција коју имају је да нам кажу нешто више о оном периоду живота јунака који није обухваћен временом радње, а који је имао јак утицај на формирање његовог карактера и тренутног стања. Друга функција им је да нам кажу шта се десило између две појаве, сцене или два дела драме. Дакле, прва тип ових дидаскалија говори о прошлости јунака, о догађајима који су се десили пре оних који су обухваћени радњом драме, док други тип говори о догађајима који су се десили између два догађаја који су обухваћени радњом. Први тип дидаскалија учествује у изградњи лика, док други тип утиче на радњу драме тј. допуњује је. Управо ова места најбоље сведоче уплив прозе у драму, јер у њима видимо како „романескна темпоралност осваја позоришни простор” (Саразак 2009: 26). 
Догађаји из прошлости који нису обухваћени радњом драме, а учествују у изградњи лика

Уводна дидаскалија у драми Шине говори о периоду живота ликова који није обухваћен радњом драме, али који на њу утиче - „Весели, Заробљеница и Психолог су мало старији од осталих, што значи да су провели младост пре рата. / Масни је доста старији. / Гадни, Дебил и Јунак су младићи који су на почетку рата били у регрутном узрасту" (Марковић 2014: 065).

Кроз читаву драму припадници насилне генерације (они који су на почетку рата били у регрутном узрасту) делују по аутоматизму. Они су насиље прихватили и као решење за неки други облик насиља. Старија генерација, пак, препознаје насиље као такво и има потребу да се против њега бори. То што су једни расли у периоду рата, а други пре, мотивише и објашњава овакве њихове природе и поступке.

Догађаји који нису обухваћени радњом драме, а десили су се између два догађаја обухваћена радњом

Постоје и дидаскалије које сведоче проток времена унутар саме радње и тиме повезују делове драме. У драми Шине таква је следећа: „Весели и Рупица. / Рупица је у белој хаљини, има ожиљак око врата, или неку траку.” (Marković 2014: 114). Рупица је у рају Заробљеница, ту информацију нам ауторка даје још у уводној дидаскалији. Сцена када јој Гадни говори: „Сада смо само ти и ја” (Марковић 2014:102) ту је и прекинута. Цитираном дидаскалијом видимо најпре да је прошло извесно време од тог тренутка, а затим и сазнајемо шта се десило након прекида сцене (она је задављена или заклана). Ова дидаскалија припада уводном типу, јер нам даје информације о томе у каквом се стању или атмосфери оно што следи дешава.

\section{Закључак}

У овом раду приказане су и анализиране дидаскалије као тип драмског говора који се јавља у драмама Милене Марковић. Природа дидаскалија, које се јављају као један од доминантних типова говора у стваралаштву ове ауторке, условила је поделу рада на четири поглавља. У оквиру једног поглавља представљено је једно од својстава дидаскалија и анализиран је његов утицаји како на радњу драме тако и на њене друге аспекте. 


\begin{tabular}{|c|c|c|}
\hline & \multicolumn{2}{|l|}{ ДИДАСКАЛИЈЕ } \\
\hline \multirow{3}{*}{$\begin{array}{l}\text { УТИЦАЈ НА } \\
\text { РАДЊУ } \\
\text { ДРАМЕ }\end{array}$} & \multicolumn{2}{|c|}{$\begin{array}{l}\text { Уводне дидаскалије } \\
\text { Претходе одређеној сцени или појави и уводе у радњу која следи } \\
\text { дају додатна објашњења }\end{array}$} \\
\hline & \multicolumn{2}{|c|}{$\begin{array}{l}\text { Средишње дидаскалије } \\
\text { Уметнуте су између реплика јунака и примарна тематика им је } \\
\text { насиље }\end{array}$} \\
\hline & \multicolumn{2}{|c|}{$\begin{array}{l}\text { Финалне дидаскалије } \\
\text { Налазе се на крају неке сцене или појаве и углавном дају догађаје } \\
\text { којима радња сцена која им претходи добија свој крајњи исход }\end{array}$} \\
\hline \multirow{5}{*}{$\begin{array}{l}\text { УТИЦАЈ } \\
\text { НА ДРУГЕ } \\
\text { АСПЕКТЕ } \\
\text { ДРАМЕ }\end{array}$} & \multicolumn{2}{|l|}{ Декор } \\
\hline & Чему јунак тежи / чему жели да припада & $\begin{array}{l}\text { Атмосфера у којој се } \\
\text { радња догађа }\end{array}$ \\
\hline & \multicolumn{2}{|c|}{$\begin{array}{l}\text { Упутства за глумце } \\
\text { Омогућавају гледаоцима да критички посматрају, а не да се } \\
\text { идентификују (Брехтов метод глуме) }\end{array}$} \\
\hline & \multicolumn{2}{|l|}{ Догађаји који нису покривени радњом драме } \\
\hline & $\begin{array}{l}\text { Сведоче проток времена унутар саме } \\
\text { радње }\end{array}$ & $\begin{array}{l}\text { Догађаји из прошлости } \\
\text { којиучествујууизградњи } \\
\text { и карактеризацији лика }\end{array}$ \\
\hline
\end{tabular}

Најпре је у оквиру првог поглавља анализиран утицај дидаскалија на радњу драме. Овом анализом утврђено је да дидаскалије утичу на радњу драме и да се у зависности од природе њиховог утицаја могу издвојити три типа дидаскалија: уводне дидаскалије (припремају нас и уводе у радњу која следи), средишње дидаскалије (служе за приказ насиља у оквиру одређене сцене) и финалне дидаскалије (приказују крајњи исход сцене).

У оквиру другог поглавља представљен је декор као својство дидаскалија и његовом анализом утврђено је да он учествује у изградњи лика тако што представља оно што јунак није, али би желео да буде и да се декором представља специфично стање и атмосфера у којој се радња дешава. 
Анализом упутстава за глумце, као једног од својстава дидаскалија, закључено је да велики утицај на драме Милене Марковић има Брехтово стваралаштво и епско позориште.

Дидаскалије имају и својство да дају друге битне информације, а које говоре о догађајима који нису обухваћени самом радњом драме. Анализа је показала да такви догађаји најпре утичу на изградњу ликова, а затим и на саму радњу драме повезујући догађаје који су у њој драматизовани.

\section{ЛИТЕРАТУРА}

Брехт 1966: Bertolt, Breht. Dijalektika u teatru. Beograd: Nolit.

Гургурис 2016: Gurguris, Statis. Da li književnost misli. Beograd: Fakultet za medije i komunikacije.

Иберсфелд 1982: Ibersfeld, An. Čitanje pozorišta. Beograd: Vuk Karadžić.

Internacionalni rečnik pozorišnih termina. Priredili Kenet Ria i Ričard Sodern. Beograd: Gea, 1997.

Јакшић Провчи 2009: Jakšić Provči, Branka. Tipovi govornih iskaza i njihova funkcija u dramama Dušana Kovačevića. Pančevo: Sveske br. 94.

Јанков 2011: Jankov, Sonja. Uloga poezije u post-teatru Milene Marković. Zbornik za jezike i književnosti Filozofskog fakulteta u Novom Sadu. Knjiga I. Novi Sad: Filozofski fakultet Univerziteta u Novom Sadu.

Језеркић/Јованов 2006: Jezerkić, Vesna. і Jovanov, Svetislav. Predgovor. Predsmrtna mladost: antologija najnovije srpske drame: (1995-2005). Deo 1. Novi Sad: Sterijino pozorje.

Клоц 1995: Kloc, Folker. Zatvorena i otvorena forma u drami. Beograd: Lapis.

Leksika moderne i savremene drame. Priredio Žan - Pjer Sarazak. Vršac: Književna opština Vršac, 2009.

Лукач 1978: Lukač, Đerđ. Istorija razvoja moderne drame. Beograd: Nolit.

Марковић 2014: Marković, Milena. Drame. Beograd: LOM.

Марковић (б), Милена. Робови смо прасећег идеализма. Интервју у Недељьник. < https://arhiva.nedeljnik.rs/nedeljnik/portalnews/milena-markovicrobovi-smo-praseceg-idealizma $>$. Последњи приступ 18. 11. 2019. године.

Марковић (в), Милена. Младобосанцима је Ниче био важан. Интервју у Политика. $<$ http://www.politika.rs/scc/clanak/280042/Mladobosancima-je-Nicebio-vazan>. Последњи приступ 18.11.2019. године.

Medenica, Ivan. Rekonstrukcija kao model rediteljske interpretacije dramske klasike. I Milićević, Ognjenka. Smrt Tarelkina ili kontinuitet zla. Teatron, br. 119/120, 153, 154-155, 156-157. Beograd: Muzej pozorišne umetnosti Srbije. 
Мелхингер 1989: Melhinger, Zigfrid. Povijest političkog kazališta. Zagreb: Grafički zavod Hrvatske.

Moderna teorija drame. Priredila Mirjana Miočinović. Beograd: Nolit, 1981.

Пискатор 1985: Piskator, Ervin. Političko kazalište. Zagreb: Centar za kulturnu djelatnost.

Пфистер 1991: Pfister, Manfred. The Theory ana Analysis of Drama. Cambridge University Press.

Rečnik književnih termina, Beograd: Institut za književnost i umetnost Beograd, 2001.

Сонди 1995: Sondi, Peter. Teorija moderne drame. Beograd: Lapis.

Сувајџић 2012: Сувајџић, Бошко. Дновиде воде. Нови Сад: Orpheus.

Целман 2015: Celman, Štefani. Porodične konstelacije u građanskoj tragediji. Teorija dramskih žanrova. Novi Sad: Pozorišni muzej Vojvodine.

Шекнер 1992: Šekner, Ričard. Ka postmodernom pozorištu: između antologije i pozorišta. Beograd: Institut za pozorište, film, radio i televiziju, FDU.

Marija Mijailović

\title{
STAGE DIRECTIONS AS A TYPE OF SPEECH IN DRAMATIC CREATIVITY OF MILENA MARKOVIĆ
}

\author{
Summary
}

In this paper will be presented and analyzed the stage directions as a type of dramatic speech that is noticed in dramas of Milena Marković. Stage directions are standing out as a type of dramatic speech that contribute to the construction of fabula and the ideas of the dramas. They are, in fact, the necessary tool for creating the complete dramatic piece. Functions that this type of speech has in dramas of Milena Marković, have imposed certain composition of chapters, or more precisely, every chapter is examining how certain feature of the stage directions is impacting, first the fabula itself, and then the other aspects of it. Analysis of this type of dramatic speech will cover the next dramas of this author : The Pavilions, The Rails, The ship for dolls, Simeon the Fondling, The Forest is glowing, Wire and Dragonkiller.

Keywords: modern serbian drama, stage directions, decor, manuals for actors, Milena Marković, epic theater 